\title{
SPINAL MUSCULAR ATROPHY
}

\author{
Seema Rai1 ${ }^{1}$ Santosh Bhalke², Rita Hajela ${ }^{3}$
}

\section{HOW TO CITE THIS ARTICLE:}

Seema Rai, Santosh Bhalke, Rita Hajela. "Spinal Muscular Atrophy". Journal of Evolution of Medical and Dental Sciences 2015; Vol. 4, Issue 71, September 03; Page: 12468-12469, DOI: 10.14260/jemds/2015/1795

ABSTRACT: Spinal muscular atrophy is genetic disorder in which anterior horn cells in spinal cord and motor nuclei of brain stem are progressively lost. The mechanism is defect in programmed cell death, wherein the deletion of cells (A normal process during gestation) continues after birth. We are reporting a case of 25 month old male with spinal muscular atrophy type 2 .

25 month old male presented with generalized hypotonic born at term gestation, product of non-consanguineous marriage, with developmental delay.

On examination muscular atrophy was present in bilateral lower limbs, generalised hypotonia present. Deep tendon reflexes absent. Power grade 3 in lower limbs and grade 4 in upper limbs. Genetic study showed deletion of exon $7 \& 8$ of SMN1 gene. EMG showed neurogenic pattern of fibrillation.

KEYWORDS: Atrophy, hypotonia, Apoptosis, Fasiculations.

INTRODUCTION: DISCUSSION: Spinal muscular atrophy is characterized by degeneration of motor neuron in anterior cells and motor nuclei in brainstem. SMA is of three types and associated with homozygous deletion of survival motor neuron gene in 5q 13.[1,2] The childhood SMA are important cause of mortality and morbidity with incidence of 1in 6000-10000 live births.[3]

SMA is classified into three types; in type 1 severe generalized hypotonia is present. Muscle mass is thin. Deep tendon stretch muscle reflexes are absent. Patients with type 1 SMA presents in first 6 month of life. More than $65 \%$ die by 2 years.[4]

Type 2 characterized by progressive weakness of muscles. Patients with this type are able to suck, swallow in early infancy, confined to wheelchair by school years. ${ }^{[4]}$

Type 3 is mildest form of SMA shows progressive weakness proximal in distribution involving shoulder girdle. Patient are ambulatory. Longevity can extend well into middle adult life.[4]

DIAGNOSIS: EMG will show spontaneous discharges (fibrillation, fasciculations) at rest.[5] The serum creatine kinase is usually normal. Deletion in survival motor neuron (SMN1) gene is identified in 92\% of all classical SMA patients.[6]

TREATMENT: No medical treatment is able to delay the progression. Valproic acid can be given as it increases SMN 2 protein and sodium butyrate may slow the progression but do not alter the course of disease in all patients.[7] 


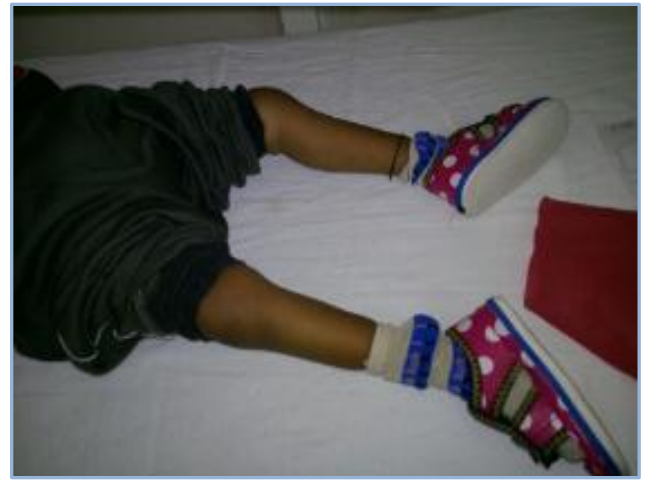

Fig. 1: Showing Atrophy of Muscles in Lower Limbs

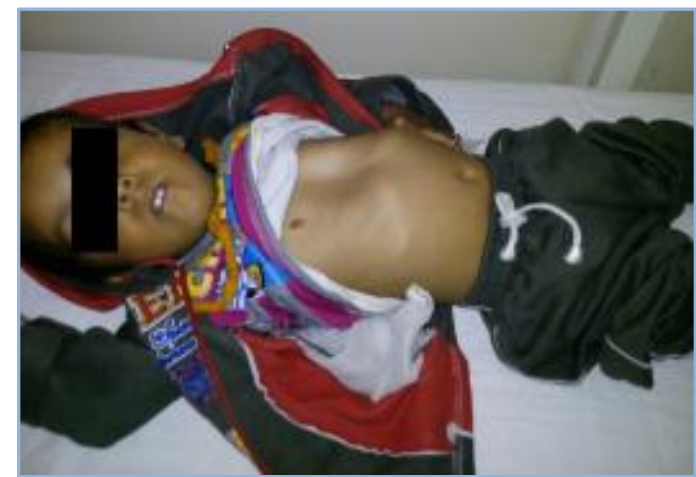

Fig. 2: Showing Atrophy of Intercoastal Muscles

\section{BIBLIOGRAPHY:}

1. Lefebvre S, Burglen L, Reboullet S, Clermont O, Burlet P, Viollet L; identification and characterization of spinal muscular atrophy determining gene cell 1995;80:155-65.

2. Jayesh sheth, Harsh patel, Sanjiv Mehta, Stuti tewan and frenny seth: clinical and molecular characterization of patients with gross hypotonia and impaired lower motor neuron function; Indian pediatr 2013; 50:591-593.

3. Peam JH; classification of spinal muscular atrophy, Lancet 1980; 1: 919-922.

4. Radhakrishnan VV, Nair MD, Kuruvilla A, Anandan R: spinal muscular atrophy a clinic pathological analysis. 1997 Sep-Oct; 64(5):687-91.

5. Fenichel GM: clinical pediatric neurology; a sign and symptom approach $3^{\text {rd }}$ Ed WB Saunder Pennysylvania 1997:153-204.

6. Rodrigues NR, Owen N, Talbot K et al: gene deletion in spinal muscular atrophy J Med Genetics 1996; 33:93-96.

7. Chang JG, Hsieh-li HM, Jongs yJ et al: treatment of spinal muscular atrophy by sodium butyrate Proc Natl Acad Sci 2001; 98: 9808-9813.

\section{AUTHORS:}

1. Seema Rai

2. Santosh Bhalke

3. Rita Hajela

\section{PARTICULARS OF CONTRIBUTORS:}

1. Assistant Professor, Department of Pediatrics, Maharishi Markandeshwar University and Hospital, Solan.

2. Professor, Department of Pediatrics, Maharishi Markandeshwar University and Hospital, Solan.

FINANCIAL OR OTHER COMPETING INTERESTS: None
3. Assistant Professor, Department of Pediatrics, Maharishi Markandeshwar University and Hospital, Solan.

\section{NAME ADDRESS EMAIL ID OF THE CORRESPONDING AUTHOR:}

Dr. Seema Rai,

Dev Bhoomi Green Valley D-15,

Deonghat Solan-173212, Himachal Pradesh.

E-mail: seemadoc98@yahoo.co.uk

Date of Submission: 16/08/2015.

Date of Peer Review: 17/08/2015.

Date of Acceptance: 29/08/2015.

Date of Publishing: 03/09/2015. 